\title{
Phytochemical-constituents, safety and efficacy of commonly used medicinal plants for the treatment of malaria in Ethiopia-a review
}

\begin{abstract}
Background: Malaria is among the ten top leading causes of morbidity and mortality in children under-5 years. Due to the rise of drug-resistant parasites and limited therapeutic efficacy of the available drugs, there is a need to search novel antimalarial drugs from medicinal plants commonly utilized as traditional medicines. Traditional medicines are often more available, affordable, sometimes are perceived as more effective than conventional antimalarial drugs, cultural acceptable and the relatively lower cost. Hence traditional medicine becomes the novel candidate for the search and development of drugs for the prevention and treatment of malaria.
\end{abstract}

Objective: The present study aimed to review phytochemical constitute, safety and efficacy commonly used medicinal plants for malaria treatment in Ethiopia.

Methods: A web-based literature search was done by using scientific databases including Pub Med, Science Direct, Web of Science and Google Scholar, with inclusion criteria of full length experimental, ethno-botanical and ethno medicinal survey articles reporting on anti-malarial medicinal plants conducted in Ethiopia.

Results: The most commonly utilized medicinal plants for the treatment of malaria were Allium sativum, Aloe pulcherrima, Aloe debrana Chrstian, Aloe Sinana, Asparagus africanus, Balanites rotundifolia, Bersama abyssnica, Calpurnia aurea, Clerodendrum myricoides, Croton macrostachyus, Dodonaea angustifolia, Echinops kebericho, Gnidia Stenophylla, Jatropha curcas, Strychnos mitis, Otostegia integrefolia, and Withania somnifera.

Conclusion and recommendation: Aqueous leaf extract of Strychnos mitis possessed a potent chemo suppression of $95.5 \%$ at a dose of $600 \mathrm{mg} / \mathrm{kg} / \mathrm{day}$. Further chemical isolation, dosage form development, clinical trial, and toxicological study is recommended.

Keywords: medicinal plants, malaria, phytochemistry, safety, efficacy
Volume 7 Issue 6 - 2019

\author{
Tigist Abera, Rekik Ashebir, Hirut Basha, \\ Eyob Debebe, Abiy Abebe, Asfaw Meresa, \\ Samuel Woldekidan \\ Traditional and Modern Medicine Research Directorate, \\ Ethiopian Public Health Institute, Ethiopia
}

\author{
Correspondence: Tigist Abera, Traditional and Modern \\ Medicine Research Directorate, Ethiopian Public Health \\ Institute, Addis Ababa, Ethiopia, \\ Email tigistabera1664@gmail.com
}

Received: October 07, 2019 | Published: November 26, 2019

\section{Introduction}

According to 2017 WHO malaria report, 394.7 million people was at risk with Plasmodium falciparum (98\%) and Plasmodium vivax (2\%). Even though death with malaria decreased from 70,700 in 2010 to 20,800 in $2016,41.5$ million malaria confirmed cases was reported in the East African region. ${ }^{1}$ P. falciparum resistance to artemisinin has been detected in five countries in the Greater Mekong sub-region. In Cambodia, high failure rates after treatment with an ACT have been detected for four different ACTs. ${ }^{2}$ Malaria remains a major public health problem in Ethiopia where only $25 \%$ of the population live in areas that are free from malaria and still among the ten top leading causes of morbidity and mortality in children under- $5 .^{3}$ Malaria transmission in Ethiopia is seasonal, depending mostly on altitude and rainfall, with a lag time varying from a few weeks before the beginning of the rainy season to more than a month after the end of the rainy season and transmission peaks bi-annually from September to December and April to May, coinciding with the major harvesting seasons. ${ }^{4}$ The prevention of malaria in Ethiopia has relied mainly on early diagnosis and treatment of infection and reduction of humanvector contact by indoor residual spraying (IRS) and long-lasting insecticidal nets (LLINs). ${ }^{5}$
The Action and Investment to defeat Malaria (AIM) 2016-2030 strategy underscored that, malaria is not only a health issue, but also a broader developmental, socio-political, economic, environmental, agricultural, educational, biological, social issue and this strategy laid strong emphasis on the importance of keeping target community at the center of the fight against malaria and highlights the need for inclusive and collaborative efforts to create a malaria-free world by $2030 .{ }^{6}$ The rise of drug-resistant parasites especially P. falciparum multidrug resistance hamper malaria containment strategies. ${ }^{7}$ In Ethiopia, artemether-lumefantrine replaced sulfadoxine-pyrimethamine (SP) in 2004 due to the increasing resistance of malaria to SP. ${ }^{8,9}$ The emergence of artemisinin resistance has raised concerns that threaten the potency of existing anti malaria's and their therapeutic effectiveness of artemisinin which have been the drugs of choice is limited by a number of factors such as short half-life, neurotoxicity, and low solubility which affects their bioavailability. Traditional medicines are often more available, affordable and sometimes are perceived as more effective than conventional antimalarial drugs. Moreover, $80 \%$ of the Ethiopian population uses traditional medicine due to the cultural acceptably of healers and the relatively lower cost than modern drugs. ${ }^{10,11}$ 
The use of plant-derived compounds for mosquito control has been used since time memorials such as quinine and artemisinin. The development of artemisinin derivatives from the traditionally used Chinese plant Qing hao, Artemisia annua L., also reaffirms the potential of ethno botanicals to provide effective drugs for the treatment of malaria. Indigenous knowledge, coupled with a history of safe use and ethno pharmacological efficacy, present a faster approach to discover new antimalarial agents. ${ }^{12}$ The increased malaria drug resistance and mosquito vectors to insecticides together with challenges of having effective anti-malaria vaccines, urgent need to search for effective, easily available, affordable and safe alternative anti-malaria drugs is necessary. ${ }^{13}$ Historically, In Ethiopia, there are documentations of medicinal plants used traditionally for the treatment of malaria in different parts of the country. However, the preclinical study such as phytochemical constituents, safety and efficacy of the medicinal plants utilized for the treatments of malaria are not documented yet. Therefore, the aims of this study were to review the phytochemical constitute, safety and efficacy commonly utilized medicinal plants for the treatment of malaria and to assess potential source of lead molecule for the development of a new drug for in Ethiopia.

\section{Methods}

The study reviewed the published literature on commonly used traditional medicinal plants for the treatment of malaria by using a webbased literature search strategy. Search for published journal articles using scientific databases including Pub Med, Science Direct, Web of Science and Google Scholar with Inclusion criteria of published full length experimental studies, ethno-botanical and ethno medicinal survey articles on anti-malarial medicinal plants conducted in Ethiopia and with exclusion criteria of data from historical documents or non-experimental studies, data from non-open access journal articles or partially accessed (abstract only) articles. The following key terms were used: Ethiopia/Ethiopian plants/Ethiopian medicinal plants/Ethiopian anti-malarial plants, Malaria/Ant malarial/ Antimalarial plants, Traditional Medicine/Traditional medicinal plants, Medicinal Plants/Medicinal herbs, Ethno botany/Ethno botanical, Ethno pharmacology/ Ethno pharmacological survey and Ethiopian traditional medicinal plants. The study uses Medley reference citation software for the Vancouver referencing style.

\section{Phytochemical constituents, safety and efficacy of commonly used medicinal plants for malaria treatment}

Aloe pulcherrima: Family; Aloaceae; vernacular Name; Hargisa dhala $(O)$

\section{Parts used; Leaf latex, root}

Phytochemistry: Two compounds were isolated from the dried latex by preparative TLC and characterized on the basis of their spectroscopic properties and by comparison with literature values Compound 1 was obtained as a pale yellow solid amorphous substance and commonly known as nataloin. Compound $\mathbf{2}$ was commonly known as 7-hydroxyaloin. ${ }^{14}$ Phytochemical investigation of the roots of $A$. pulcherrima has also resulted in the identification of three anthraquinones namely chrysophanol, aloesaponarin I and aloesaponarin II. ${ }^{9}$

Safety and toxicity: Acute toxicity studies indicated that no mortality in both the latex $(5 \mathrm{~g} / \mathrm{kg})$ and isolated compounds $(2 \mathrm{~g} / \mathrm{kg})$ was recorded within 14 days. $\mathrm{LD}_{50} \mathrm{~s}$ of the latex and the isolated compounds was beyond $5000 \mathrm{mg} / \mathrm{kg}$ and $2000 \mathrm{mg} / \mathrm{kg}$ body weight, respectively. Weak signs of toxicity such as loss of appetite, hair erection, lacrimation, tremors, convulsions, salivation and diarrhea displayed by the latex could be due to its major constituents, nataloin and 7-hydroxyaloin, as both compounds showed some signs of toxicity. ${ }^{14}$

Efficacy: The latex of the plant significantly decrease $(p<0.05)$ in the parasitaemia of test substance-treated groups, particularly those treated with a dose of $200 \mathrm{mg} / \mathrm{kg}$ and $400 \mathrm{mg} / \mathrm{kg}$ with the exception of 7-hydroxyaloin, when compared to the untreated group. Maximum percentage chemo suppression was obtained for 7-hydroxyaloin, $56.2 \%$ suppression at a dose of $200 \mathrm{mg} / \mathrm{kg}$ which is comparable with the aqueous solution of the exudate of Aloe. otallensis produced $(60.7 \%)$ parasitaemia suppression at the a dose of $300 \mathrm{mg} / \mathrm{kg} /$ day body weight. ${ }^{15}$ Both the pure compounds and latex produced the highest parasitaemia suppression at the middle dose suggested that $200 \mathrm{mg} /$ $\mathrm{kg}$ body weight might be the optimal therapeutic dose in mice. ${ }^{14}$ The other study by Dele et.al., ${ }^{9}$ showed that the antiplasmodial activities of the two aloesaponarins from the root of A. pulcherrima were strong and promising against the chloroquine-sensitive strain and the antibacterial activity of aloesaponarin II was even greater than the reference drug (gentamicin $10 \mu \mathrm{g}$ ) against $B$. subtilis.

\section{Aloe debrana Chrstian; Family; Aloaceae; vernacular}

\section{Parts used; Leaf latex}

Phytochemistry: The leaf latex of A. debrana subjected to repeated preparative TLC (silica gel) using chloroform: methanol (4:1) as a solvent system afforded two major compounds with $R f$ values of 0.65 (1) and 0.79 (2). Compound 1 was unequivocally identified as aloin (10-C- $\beta$-D-glucopyranosyl-1, 8-dihydroxy-3-(hydroxymethyl)$9(10 \mathrm{H})$-anthracenone). Compound 2 also obtained as a pale yellow amorphous substance with $\mathrm{R} f$ value of 0.79 in $\mathrm{CHCl}_{3} / \mathrm{MeOH}(4: 1)$. The structure of compound $\mathbf{2}$ was established as $(E)$-2-(1-hydroxy2 -methylpropyl) - 8-(6'-O-Cinnamoyl)- $\beta$-D-glucopyranosyl7-methoxy-5-methyl-chromone. ${ }^{16}$

Safety and toxicity: No signs of toxicity or mortality were observed in mice after oral administration of the latex of $A$. debrana, even at doses as high as $5000 \mathrm{mg} / \mathrm{kg}$ signifying that the oral $\mathrm{LD}_{50}$ was greater than $5000 \mathrm{mg} / \mathrm{kg}$. Acute toxicity of the crude methanol extract of $A$. debrana indicated no mortality of mice within $24 \mathrm{hrs}$ up to $3000 \mathrm{mg} /$ $\mathrm{kg}$ which is comparable with $A$. percrassa, and A. camperi species at a dose of $2000 \mathrm{mg} / \mathrm{kg} .{ }^{17}$ Gross physical and behavioral observation of the experimental mice also revealed no visible signs of acute toxicity like lacrimation, hair erection, and reduction in their motor and feeding activities with crude methanol extract of $A$. debrana.

Efficacy: The latex produced a dose-dependent parasitaemia inhibition effect at various doses given orally with the highest suppression of parasitaemia $(75.02 \%)$ observed at a dose of $60 \mathrm{mg} / \mathrm{kg} / \mathrm{day}$. Although the exact mechanism of action of the latex has not been elucidated, some plant extracts are known to exert antiplasmodial activity either by causing red blood cell Oxidation or by inhibiting protein synthesis depending on their phytochemical constituents. Aloin showed 48.38\% parasitaemia suppression against $P$. berghei at a dose of $25 \mathrm{mg} / \mathrm{kg} /$ day. Aloin displayed the highest suppression of parasitaemia (78.31\%) at a dose of $100 \mathrm{mg} / \mathrm{kg}$. HCGMM also showed significant suppression $(p<0.05)$ against $P$. berghei at dose levels of 25,50 , and $100 \mathrm{mg} / \mathrm{kg} /$ day compared to the mice in the negative control group. The methanol extract of $A$. debrana leaves induced $73.95 \%$ parasitaemia suppression at the highest dose $(600 \mathrm{mg} / \mathrm{kg})$ and aqueous extract of the leaves of 
A. debrana at $600 \mathrm{mg} / \mathrm{kg}$ exerted $54.36 \%$ parasite suppression (18). In a similar way the other study by Tekalign et al., ${ }^{18}$ also shows Aloe debrana species have suppression activity against $P$. berghei malaria parasite.

\section{Aloe. Sinana; Family; Aloaceae}

\section{Parts used; Leaf latex}

Phytochemistry: Three compounds were isolated from the leaf latex of A sinana: microdontin aloin and aloinoside. ${ }^{10}$

Safety and toxicity: No sign of toxicity or mortality was observed in mice upon oral administration of the latex of $A$. sinana, and the isolated compounds up to the dose of $5000 \mathrm{mg} / \mathrm{kg}$. It indicated that that the oral $\mathrm{LD}_{50}$ is greater than $5000 \mathrm{mg} / \mathrm{kg}$ for both the latex and isolated compounds. ${ }^{10}$

Efficacy: The latex had showed dose dependent antimalarial activity, at 100,200 and $400 \mathrm{mg} / \mathrm{kg} /$ day dose revealed a $53.4,62.3$ and $68.2 \%$ suppression, respectively. All the isolated compounds possess significant antimalarial activity in 4-day suppression test the highest was recorded in aloinoside. The presence of remarkable suppression could be seen also from the life-prolonging (prolongation of the mean survival time) potential of the isolated compounds in malariainfected mice. ${ }^{10}$ The other study indicated that Aloe sinana Reynolds is endemic to Ethiopia, where its leaf latex is traditionally used in and around the town of Debre Sina and other central highlands as a wound-healing agent, insecticide and for the treatment of snake bite and malaria by the local people. ${ }^{19}$

Asparagus africanus; Family; Liliaceae; vernacular name; "Seriti (O) and Kestencha (A)

\section{Parts used; root and aerial parts}

Phytochemistry: The qualitative study revealed that the plant contained several biologically active major secondary metabolites such as Polyphenols, saponins, phenolic glycosides, phytosteroids and terpens were identified in roots parts of the plant alkaloids, polyphenols, tannins, phenolic glycosides, phytosterols and terpens were revealed in aerial parts(20).

Safety and toxicity: The hydroalcoholic extracts showed no lethality to mice at $5,000 \mathrm{mg} / \mathrm{kg}$, which is 25 times the median effective dose and no gross behavioural and physical changes were revealed. Intraperitoneal administration also did not produce lethality at doses of up to $1000 \mathrm{mg} / \mathrm{kg}^{20}$

Efficacy: The hydroalcoholic extracts of the root and aerial parts of the plant have shown parasite suppressive effects on $P$. berghei infected Swiss albino mice in a dose-related fashion. A high level (46.12 $\%$ inhibition with the $600 \mathrm{mg} / \mathrm{kg}$ ), A. africanus roots and a $40.73 \%$ inhibition of $A$. africanus aerial parts also observed. Therefore, the highest level of inhibition (46.12\%) was observed in $600 \mathrm{mg} / \mathrm{kg}$ of $A$. africanus roots. ${ }^{20}$

\section{Balanites rotundifolia; Family; Balanitaceae}

\section{Parts used; Leaf}

Phytochemistry: Phytochemical screening of the $80 \%$ methanol leaf extract of $B$. rotundifolia revealed the presence of alkaloids and cardiac glycosides. Terpenoids, flavonoids, and tannins were not detected. ${ }^{21}$
Safety and toxicity: Acute toxicity test at the limit test dose of $2,000 \mathrm{mg} / \mathrm{kg}$, neither mortality nor changes related to behavioral, autonomic, neurological, and physical profile were observed during the 14 days' follow-up. ${ }^{21}$

Efficacy: The extract at a dose of 100, 200 and $400 \mathrm{mg} / \mathrm{kg}$ reveled that a $37 \%, 42 \%$ and $67 \%$ parasite suppression, Despite a decrease in parasitaemia level, treatment with the crude leaf extract of $B$. rotundifolia did not prevent loss of body weight in $P$. berghei-infected mice. B. rotundifolia extract treatment also prevented a significant decrease in packed cell volume in a dose-dependent manner. The decrease in packed cell volume was highest for $100 \mathrm{mg} / \mathrm{kg}(\mathrm{P}<0.001)$ followed by $200 \mathrm{mg} / \mathrm{kg}(\mathrm{P}<0.05)$ and $400 \mathrm{mg} / \mathrm{kg}(\mathrm{P}>0.05)$ as compared to chloroquine $25 \mathrm{mg} / \mathrm{kg}$. For the curative test, in which the parasitaemia is allowed to establish, $400 \mathrm{mg} / \mathrm{kg}$ demonstrated comparable effect with chloroquine in preventing the decrease in rectal temperature in reference to normal control, B. rotundifolia $100 \mathrm{mg} / \mathrm{kg}$, and $200 \mathrm{mg} / \mathrm{kg}$ $(\mathrm{P}<0.001$ for all cases). The extract at $400 \mathrm{mg} / \mathrm{kg}$ increased the body weight greater than the chloroquine dose, but it was not statistically significant. $^{21}$

Bersama abyssnica fresen; Family; Melianthaceae; vernacular name; Azamir(A)

\section{Parts used; root bark}

Phytochemistry: The aqueous and hydroalcoholic extraction of $B$. abyssinica shows the presence of many secondary metabolites tannins, flavonoids, phenolic glycosides, phytosteriods, and saponins. ${ }^{22}$

Safety and toxicity: B. abyssinica hydroalcoholic extract showed signs of acute toxicity including diarrhea, gasping, abdominal writhing, muscle weakness (signs of paralysis), rough hair coat and depression. The $\mathrm{LD}_{50}$ of $B$. abyssinica was calculated to be $5044 \mathrm{mg} / \mathrm{kg}$ body weight which is about 12.6 times the maximum effective dose tested $(400 \mathrm{mg} / \mathrm{kg}){ }^{22}$

Efficacy: The crude extracts were partially reduced parasitaemia and prolonged survival time of mice infected with $P$. berghei but, the hydroalcoholic extract of $B$. abyssinica was the more active and caused $30.01 \%$ reduction of parasitaemia at doses of $400 \mathrm{mg} / \mathrm{Kg}$ on day $4(P<0.05){ }^{22}$ An ethnobotanical study of medicinal plants in East Welega Zone Wayu Tuka Distric by Moa et al., ${ }^{23}$ indicated that $B$. abyssinica also used for the treatment of ascaris.

Calpurnia aurea; Family; Fabaceae; vernacular name; chekata(O), digita(A)

\section{Parts used; leaf}

Phytochemistry: The result of preliminary phytochemical screening of powdered plant material of $C$. aurea showed the presence of several secondary metabolites including alkaloids, cardiac glycosides, flavonoids, phenols, phytosteriods, saponins, terpenoids and tannins. ${ }^{24}$

Safety and toxicity: The hydromethanolic leaf extract of $C$. aurea acute toxicity revealed the absence of mortality up to the dose level of $300 \mathrm{mg} / \mathrm{kg}$ body weight of extract administered orally. The oral median lethal dose $\left(\mathrm{LD}_{50}\right)$ of the extract could be greater than $300 \mathrm{mg} /$ kg body weight of the extract.

Efficacy: The result of the 4-day suppressive test indicated that at three dose levels $(15,30$ and $60 \mathrm{mg} / \mathrm{kg}$ body weight) of the extract produced significant $(\mathrm{p}<0.001)$ parasitaemia reduction compared to negative control. The 15 and $60 \mathrm{mg} / \mathrm{kg}$ body weight of extract resulted 
in higher anti-plasmodial activity (46.14 and $51.15 \%$, respectively), followed by the $30 \mathrm{mg} / \mathrm{kg}$ body weight $(43.34 \%)$. In the 4-day suppressive test, the effect of leaf extract of $C$. aurea on packed cell volume (PCV) is indicated that the extract at dose levels of 15 and $30 \mathrm{mg} / \mathrm{kg}$ body weight had shown some activity on prevention against PCV reduction when compared to negative control but $60 \mathrm{mg} / \mathrm{kg}$ body weight of extract had not shown a significant $(\mathrm{p}>0.05)$ prevention activity against PCV reduction compared to negative control. ${ }^{24}$

Clerodendrum myricoides; Family; vernacular name; misrch (A)

\section{Parts used; leaf, root}

Safety and toxicity: The acute toxicity study on crude leaf extract of $C$. myricoides by Tekalign et al., ${ }^{18}$ indicated that no mortality of mice within $24 \mathrm{hrs}$ up to $3000 \mathrm{mg} /$. Hayelom et al., ${ }^{25}$ also investigated that treatment with the aqueous root extract of $C$. myricoides revealed that there was no behavioral change at $100 \mathrm{mg} / \mathrm{kg}$ body weight/day treatment as compared to the controls. However, the mice treated with $400 \mathrm{mg} / \mathrm{kg}$ body weight/day of the aqueous extract showed some behavioral changes. A single-dose administration of $1134 \mathrm{mg} /$ $\mathrm{kg}$ body weight/day aqueous root-extract showed behavioral changes which include: horripilation, difficult to breathe, grooming, and asthenia which were followed by the death of animals after some hours. Chronic treatments with C. myricoides extracts in mice causes reduction in body weight gain, damage to the liver and kidney and changes in some hematological and biochemical parameters in mice.

Efficacy: After four days treatment of mice with crude leaf methanol extract of different doses of $C$. myricoides, the mean parasitaemia of the test groups were found to be $6.52 \pm 0.58 \%$ in $300 \mathrm{mg} / \mathrm{kg}$ and $5.92 \pm 0.38 \%$ in $500 \mathrm{mg} / \mathrm{kg}$ while the corresponding value of the negative control group were $25.73 \pm 1.57 \%$. Statistical analysis using Scheffe's procedure indicated that groups of mice treated with $300 \mathrm{mg} /$ $\mathrm{kg}$ and $500 \mathrm{mg} / \mathrm{kg}$ of C. myricoides leaf methanol extract showed statistically a significant difference in parasitaemia level as compared to the negative control group $(\mathrm{P}<0.05)$. The highest suppression of parasitaemia was observed at the dose of $500 \mathrm{mg} / \mathrm{kg}$ body weight of mice. Ethyl acetate soluble and insoluble extracts (residue) at a dose of $150 \mathrm{mg} / \mathrm{kg}$ of C. myricoides leaves showed a suppressive effect of $61.30 \%$ and $69.31 \%$ respectively which have statistically significant difference as compared to negative control $(\mathrm{P}<0.05)$. While the suppressive effect of hexane extract was $16.21 \%$ which is not significantly different from the negative control. Residue and ethyl acetate extracts of $C$. myricoides leaf had better activity. ${ }^{26}$ In similar way the other study investigated methanol extract of $C$. myricoides showed 82.5 suppression of parasitaemia at the dose of $600 \mathrm{mg} / \mathrm{kg}$ body weight of mice. ${ }^{18}$

Croton macrostachyus; Family; Euphorbiaceae; vernacular name; Bissana (A); Bekenisa(O)

\section{Parts used; leaf, root and fruit}

Phytochemistry: The hydroalcoholic crude extract of the leaves of C. macrostachyus revealed the presence of alkaloids, saponins, phenolic compounds, cardiac glycosides, terpenoids and flavonoids in addition to these compounds hydroalcoholic crude extracts of the fruit and root also revealed the presence of tannins. Anthraquinones and phlabotannins were absent from the crude extract of leaf and fruit, however, present in the root extract. ${ }^{27,28}$ Apart from the one compound, triterpene was isolated from the ethanol leaf extract. ${ }^{27}$
Safety and toxicity: The acute toxicity study crude and the solvent fraction of leaf indicated that the extract caused no mortality and no visible signs of overt toxicity at doses of 2 and $5 \mathrm{~g} / \mathrm{kg}$ within the 14 days follow up periods. However, The crude extracts from the fruit and root did not show mortality and sign of toxicity up to a dose of $2 \mathrm{~g} / \mathrm{kg}$ within the 14 days $(28-30)$. Sub-acute toxicity test of methanol and aqueous extracts of $C$. macrostachyus leaf on day 4 showed no statistically significant difference $(\mathrm{P}>0.05)$ in all the hematological parameters. Significant $(\mathrm{P}<0.05)$ body weight loss at the highest dose i.e. $1000 \mathrm{mg} / \mathrm{kg}$ (from $30.20 \mathrm{gm}$ to $25.90 \mathrm{gm}$ ) and body weight gain at $500 \mathrm{mg} / \mathrm{kg}$ (from $31.34 \mathrm{gm}$ to $33.58 \mathrm{gm}$ ) in aqueous extract and in negative control group (from $26.54 \mathrm{gm}$ to $29.36 \mathrm{gm}$ ) was observed. ${ }^{30}$ Similarly the other study confirms that acute toxicity with ethyl acetate, methanol, and aqueous extract of C. macrostachyus from stem bark was safe, however, the mice of the isobutanol extract treatment group showed signs of acute toxicity such as gasping, abdominal writhing, muscle weakness, rough hair coat and depression. ${ }^{31}$

Efficacy: Research by Laychiluh et al., ${ }^{29}$ revealed that percentage of parasitaemia measured in the 4 day test was reduced by the crude leaf extract in $P$. berghei infected mice which is comparable to study done by Tigist et al. ${ }^{30}$ C. macrostachyus $600 \mathrm{mg}$ exhibited a significant parasite suppression compared to other doses of the extract and the activity was almost comparable to that of chloroquine. Analysis of rectal temperature revealed that $80 \%$ methanol extract of $C$. macrostachyus caused significant attenuation of reduction in temperature of $P$. berghei infected mice in a dose-dependent manner. The rank order of parasitaemia inhibition of the solvent fractions was chloroform $(75.9 \%)>$ methanol $(64.2 \%)>$ aqueous $(38.8 \%)$. Maximum inhibition $(82.3 \%$ ) was attained with $600 \mathrm{mg} / \mathrm{kg}$ dose of the fraction. The other investigation by Laychiluh et al., ${ }^{28}$ Indicated that, the fruit extract $600 \mathrm{mg}$ and root extract $600 \mathrm{mg}$ of C. macrostachyus exhibited a significant parasite suppression $83 \%$ and $88 \%$ respectively, compared to the other doses, the root extract had better suppressive activity and it increased survival time better than the fruit extract. Analysis of the rectal temperature revealed that $80 \%$ methanolic fruit extract of C. macrostachyus significantly prevented the reduction of temperature in a dose-dependent manner $(\mathrm{p}<0.01$ for fruit $200 \mathrm{mg}$ and fruit $400 \mathrm{mg} ; \mathrm{p}<0.001$ for fruit $600 \mathrm{mg}$ ). The root extract produced a better reduction of rectal temperature and parasitaemia inhibition activity than the fruit extract. The suppression was dose-dependent and $88 \%$ for root extract $600 \mathrm{mg}$, which is more effective than the suppression effects of the ethyl acetate extract of stem bark (82\%) of C. macrostachyus investigated by Jackie et al. ${ }^{31}$ Leaf, fruit, root and stem bark of C. macrostachuys have significant antiplasmodial activity against $P$. berghei both in chemotherapeutic and in chemoprotective way. Crushed leaves of $C$. macrostachyus are also boiled in water mixed with Allium sativum and taken orally as a remedy for malaria treatment, in addition to this C. macrostachyus have potent larvicidal activity against the malaria vector An Arabiensis. ${ }^{28-33}$

\section{Dodonaea angustifolia; Family; Sapindaceae; vernacular name;} $\operatorname{Ketketa(A)}$

\section{Parts used; leaf, root}

Phytochemistry: Three compounds isolated from the active ethyl acetate fractions, pinocembrin, the flavanol santin, and the clerodane diterpene 2-hydroxy-15, 16-epoxyceloda- 3, 13(16), 14-trien-18oic acid which is similar to the investigation of other species of $D$. angustifolia. ${ }^{34,35}$ 
Safety and toxicity: The acute toxicity study indicated that crude leaf extract of $D$. angustifolia shows no mortality of mice within $24 \mathrm{hrs}$ up to $3000 \mathrm{mg} / \mathrm{kg}$ and solvent fraction of methanolic root extract up to a dose of $2000 \mathrm{mg} / \mathrm{kg} \cdot{ }^{18,36}$

Efficacy: The antiplasmodial activities of the ethanol extract of the leaves of D. angustifolia at a higher dose $(300 \mathrm{mg} / \mathrm{kg})$ inhibited the parasites by $77.20 \%$ but, ethyl acetate fractions, suppression of parasitaemia by $82.00 \%$ at the dose of $300 \mathrm{mg} / \mathrm{kg} .{ }^{18,26,34}$ Fractionation showed the ethyl acetate soluble portion of the $80 \%$ aqueous methanol extract of the leaves of $D$. angustifolia suppressed parasitaemia in $P$. berghei infected mice significantly $(80.28 \%$ at $150 \mathrm{mg} / \mathrm{kg}) .{ }^{34} \mathrm{The}$ n-butanol fraction of methanolic root extract of $D$. angustifolia significantly reduced parasitaemia level as compared to the control group $(\mathrm{P}<0.001)$ and the highest suppression $(67.51 \%)$ was seen with the dose of $600 \mathrm{mg} / \mathrm{kg}$ body weight which is less potent and effective than ethyl acetate fractions of leaf of D. angustifolia. ${ }^{34,36}$

Echinops kebericho; Family; Asteraceae: vernacular name; kebercho(A)

\section{Parts used, root}

Phytochemistry: A total of 83 compounds were identified from EO (Essential Oil) of E. kebericho. Although sesquiterpenoids were most abundant, many monoterpenoids at low concentration levels were also detected $^{37,38}$ which is similar and comparable with the other species of Echinops. ${ }^{39,40} \alpha$-Guaiene and $\beta$-santalene and the monocyclic sesquiterpenoid hydrocarbon $\beta$-elemene, were also observed in the solid phase microextraction in relatively large amounts compared to the hydro distilled E. kebericho essential oil. ${ }^{37}$

Safety and toxicity: Acute toxicity studies of graded doses of hydroalcoholic extract of E. kebericho (up to a dose of $5,000 \mathrm{mg} / \mathrm{kg}$ ) did not produce significant changes in behaviours, such as alertness, motor activity, breathing, restlessness, diarrhea, convulsions, coma, and appearance of the animals. No death was observed up to the dose of $5 \mathrm{~g} / \mathrm{kg}$ body weight, indicating that the median lethal dose $\left(\mathrm{LD}_{50}\right)$ could be greater than $5 \mathrm{~g} / \mathrm{kg}$ body weight in mice. ${ }^{41}$

Efficacy: The chemo suppression effect of E. kebericho was $16.93 \pm 1.17 \%, 29.46 \pm 1.93 \%$ and $57.29 \pm 1.76 \%$ for $200,350,500 \mathrm{mg} /$ $\mathrm{kg} /$ day doses, respectively. The chemo suppressive effect produced by doses beyond $350 \mathrm{mg} / \mathrm{kg}$ was very significant $(\mathrm{P}<0.001)$ compared with the negative control. All concentrations of extract employed no significant prevention effect on weight loss of mice at all dose levels ( $>0.05$ ) compared with the control group but, prevented packed cell volume loss of mice at all dose levels $(\mathrm{P}<0.001) .{ }^{41}$ E. kebericho is as a major medicinal plants used by Ethiopian Immigrants in the USA, in Amhara, Northwestern Ethiopia, by Oromo people around Ghimbi District and in West Gojjam Zone of Ethiopia for different types of disease and surprising that E. kebericho oil exerted an extremely strong leishmanicidal effect, which was even higher than that of amphotericin B showing significant cytotoxicity. ${ }^{38,42-45}$

Gnidia Stenophylla Gilg; Family; Thymelaeaceae; vernacular name; Kataricha(O); Demer Erit(A)

\section{Parts used, root}

Phytochemistry: The genus Gnidia contain coumarins, flavonoids, chromones, lignans, neolignans and phenolic compounds. ${ }^{46,47}$

Safety and toxicity: Acute toxicity study of the aqueous root extract at $500,1000,2000$ and $4000 \mathrm{mg} / \mathrm{kg}$ did not produce any mortality in both male and female mice during the $72 \mathrm{~h}$ observation period. However, the mice treated with extract at 5000 and $6000 \mathrm{mg} / \mathrm{kg}$ body weight showed some mild symptoms of toxicity within 1-2hrs of the extract administration. Treatment with $800 \mathrm{mg} / \mathrm{kg}$ extract however, induced significant $(\mathrm{P}<0.05)$ rise in the $\mathrm{RBC}, \mathrm{HGB}$ and in $\mathrm{HCT}$ counts when compared to the control levels. Similarly, a significant $(\mathrm{P}<0.05)$ increase in basophils count was observed with $800 \mathrm{mg} / \mathrm{kg}$ body weight extract, the other study also investigated G. stenophylla Gilg root extract on did not reveal any detectable gross abnormality stomach, small intestine and large intestine..$^{48,49}$ In contrast, lymphocytes count was significantly reduced with $800 \mathrm{mg} / \mathrm{kg}$ GSG root extract as compared to the control. Serum total protein level appeared to decrease after chronic treatment with 400 and $800 \mathrm{mg} / \mathrm{kg}$ of extract in a dose-dependent manner and decrease the serum ALP, ALT and urea levels at 400 and $800 \mathrm{mg} / \mathrm{kg}$ though non significantly. No significant difference was observed in absolute and relative organ weights of extract treated and control mice of either sex. However, there was a slight, but not significant, decrease in absolute and relative weights of spleen at both doses in male mice, but not in females. ${ }^{48}$

Efficacy; Research by Samson et al., ${ }^{50}$ indicated that the aqueous fraction of G. stenophylla showed $60.62 \%$ suppression at $400 \mathrm{mg}$ / $\mathrm{kg}$ /day suppression which was the highest. The dichloromethane and butanol fractions showed less activity with about $16.73 \%$ at $400 \mathrm{mg} / \mathrm{kg} /$ day. Comparing the percentage reduction of the control and the extract treated the percentage reduction of the $400 \mathrm{mg} / \mathrm{kg}$ of the aqueous fraction treated group is significantly different $(\mathrm{P}<0.05)$ from the control while for others no significant difference $(\mathrm{P}>0.05)$ between that of the negative control.

Jatropha curcas; Family; Euphorbiaceae; vernacular name; Ayderke(A)

\section{Parts used, leaf}

Phytochemistry: The preliminary phytochemical screening of the alcoholic extract of various parts of $J$. curcas Linn revealed the presence of alkaloids, phenolic groups, flavonids, saponins, steroids, tannins, cardiac glycosides, and terpenoids, which is similar to the other species of Jatropha. Gossypiifolia. ${ }^{51,52}$

Safety and toxicity: Crude methanol leaf extract of Jatropha curcas had less toxicity against the test larvae (LC50=92.09ppm; LC90 $=241.09 \mathrm{ppm}$ ) as compared to its column chromatographic fractions $[F 1] \quad(\mathrm{LC} 50=28.65 \mathrm{ppm} ; \quad \mathrm{LC} 90=49.20 \mathrm{ppm}), \quad[F 2]$ $(\mathrm{LC} 50=30.40 \mathrm{ppm} ; \mathrm{LC} 90=49.80 \mathrm{ppm})$ and $[F 3](\mathrm{LC} 50=80.70 \mathrm{ppm}$; $\mathrm{LC} 90=123.70 \mathrm{ppm})$. Least toxicity on the test larvae was observed by column chromatographic fraction three $[F 3]$ (LC50=80.70ppm; LC90 $=123.70 \mathrm{ppm})$, another study, on the other hand, evaluated the oral acute toxicity of the aqueous and ethanol extracts from leaves of $J$. gossypiifolia, did not show any sign of toxicity in up to $2 \mathrm{~g} / \mathrm{kg}$ in rats. ${ }^{52,53}$

Efficacy: Zewdneh et al., ${ }^{53}$ revealed that the highest mortality larvicidal for the crude methanol extract was recorded at 500ppm, $99.56 \%$, while it was at $125 \mathrm{ppm}$ for the fractions $F 1$ and $F 2,100 \%$. At the $125 \mathrm{ppm}$, larval mortalities among $F 1, F 2$ and $F 3$ were not significantly different $(\mathrm{P}>0.05)$ while at $62.5 \mathrm{ppm}$, larval mortalities among $F 1, F 2$ and $F 3$ were significantly different $(\mathrm{P}<0.01)$. Crude methanol leaf extract of $J$.curcas had similar larvicidal activity to $0.5 \mathrm{ppm}$ Temephos at test concentrations ranging from $125-1000 \mathrm{ppm}$ while Column chromatographic fractions ( $F 1$ and $F 2$ ) of crude methanol leaf extract of $J$. curcas showed similar larvicidal activities 
to $0.5 \mathrm{ppm}$ Temephos at 62.5 and $125 \mathrm{ppm}$ test concentrations. This investigation is similar to study by Samuel et al., ${ }^{54}$ which indicated that $J$. glandulifera showed excellent antiplasmodial activity.

Strychnos mitis; Family; Loganiaceae; vernacular name; Yedingamst (A), mulqaa, Satto(O)

\section{Parts used, leaf}

Phytochemistry: Phytochemical screening of hydromethanolic leaves of $S$. mitis showed the presence of different secondary metabolites like alkaloids, tannins saponins, flavonoids Terpenoids, Steroid, phenols and glycosides which is comparable with other species of the plant. ${ }^{55,56}$

Safety and toxicity: Selamawit et al., ${ }^{55}$ investigated the acute toxicity study of $S$. mitis indicated that both hydromethanolic and aqueous extract of $S$. mitis leaves caused no mortality up to $2000 \mathrm{mg} / \mathrm{kg}$ oral doses within the first 24 hours as well as for the following 14 days and the experimental mice who ingested the crude aqueous, chloroform and methanol leaf extracts of $S$. mitis also did not show any indication of gross physical or behavioral changes.

Efficacy: Hydromethanolic and aquoeus extract of $S$. mitis leaves have prominent antiplasmodial activity against chloroquine sensitive $P$. berghei infected Swiss albino mice. The highest percentage suppression of hydromethanolic extract was $93.97 \%$ at $600 \mathrm{mg} / \mathrm{kg} /$ day of the extract, and percentage Suppression of aqueous extract was $95.5 \%$ at $600 \mathrm{mg} / \mathrm{kg} /$ day of the extract after four day suppressive test, which is comparable to chloroquine $(25 \mathrm{mg} / \mathrm{kg})(100 \%)$. The N-hexane fraction and the higher two doses $(200 \mathrm{mg} / \mathrm{kg}$ and $400 \mathrm{mg} / \mathrm{kg}$ ) of chloroform and aqueous fraction of $S$. mitis leaves protected the mice from body weight loss as compared to negative control after four day suppressive test, this investigation is comparable with antiplasmodial activity of other species of Strychnos, S. usambarensis, S. icaja, $S$. variabilis, S.angolensis and $S$. memecyloides. ${ }^{55,57}$

Otostegia integrefolia; Family; Lamiaceae; vernacular name; tinjut (A)

\section{Parts used, leaf}

Phytochemistry: Yiketel et al., ${ }^{58}$ and Zewdneh et al., ${ }^{59}$ investigated that Methanol extract of $O$. integrefolia has a wide range of bioactive compounds including flavonoids, phenols, terpenoids, saponins, steroids and glycosides because of its high polarity which is comparable with $O$. persica species. ${ }^{60}$ The ethyl acetate extract was also positive for flavonoids, phenols, terpenoids, saponins, steroids and glycosides, however, the petroleum ether was able to extract very limited compounds. ${ }^{58}$ Abyot et al. ${ }^{61}$ isolated a Compound, which was exhibited a molecular ion peak at $\mathrm{m} / \mathrm{z} 320$ consistent with a molecular formula of $\mathrm{C}_{20} \mathrm{H}_{32} \mathrm{O}_{3}$ from dried hydroalcoholic leaf extract of $O$. integrifolia. It was identified as the labdane diterpenoid otostegindiol based on its $1 \mathrm{H}$ and 13C NMR spectral features.

Safety and toxicity: The safety of $O$. integrifolia indicated that no signs of toxicity or mortality were observed in mice after oral administration of the total leaf extract, even at doses as high as $5000 \mathrm{mg} / \mathrm{kg}$ signifying that the oral LD50 was greater than $5000 \mathrm{mg} / \mathrm{kg}$. Sub-acute toxicity study shows no statistically significant differences $(\mathrm{P}>0.05)$ were observed when weight and packed cell volume were compared in each group between pre-treatment and post-treatment. Sign of toxicity such as change in animal behavior, lacrimation, weight loss, hair erection and mortality were not recorded both in acute and sub-acute toxicity testing which is parallel with other species of the plant. ${ }^{59-62}$ Slight reduction in packed cell volume observed in the extract-treated groups in sub-acute toxicity test might be due to the presence of saponins in the crude extract which are known to cause hemolysis by increasing the permeability of the plasma membrane. ${ }^{61}$

Efficacy: Hydroalcoholic leaf extract of $O$. integrifolia possesses potent activity against $P$. berghei malaria parasite in vivo with a maximum percent parasitaemia inhibition of 80.5 at a dose of $600 \mathrm{mg} /$ $\mathrm{kg} /$ day and revealed that the extract has dose-dependent activity with significant $(\mathrm{P}<0.001)$ parasitaemia inhibition when compared to the negative control. The crude leaf extract was able to prevent loss of body weight and reduction in packed cell volume of $P$. berghei infected mice and other findings showed that $O$. persica potentiated the effect of chloroquine on the chloroquine-sensitive $P$. berghei ${ }^{61-63}$ The labdane diterpenoids otostegindiol isolated from the active EtOAc fraction produced a dose-dependent parasetemia inhibition effect with the highest percent suppression values of 73.16 at a dose of $100 \mathrm{mg} / \mathrm{kg} /$ day which is statistically significant $(\mathrm{P}<0.001)$ compared to the negative control. ${ }^{61}$ Ethnobotanical study by Mirutse et al. ${ }^{45}$ and Getaneh et al., ${ }^{64}$ also indicated that $O$. integrifolia was used for the treatment of malaria in different parts of Ethiopia.

\section{Withania somnifera; Family; Solanaceae; vernacular name;} hanzo (O), gizawa(A)

\section{Parts used, leaf, root and root bark}

Phytochemistry: Study by Dawit et al., ${ }^{20}$ showed that tannins, alkaloids, polyphenols, flavonoids, phytosterols and phenolic glycosides, were identified in W. somnifera leaves and alkaloids, polyphenols, phenolic glycosides, phytosteroids and saponins were identified in the root barks, which is comparable to with the chemistry of other Withania species. ${ }^{65}$

Safety and toxicity: The hydro alcoholic extracts of $W$. somnifera leaves and root barks, showed no lethality at doses up to $5,000 \mathrm{mg} / \mathrm{kg}$, when given through intra gastric route (which is $25 \mathrm{MED}, 200 \mathrm{mg} / \mathrm{kg}$ ). Similarly, intra peritoneal administration of the same extracts doses of up to $1000 \mathrm{mg} / \mathrm{kg}$ did not produce lethality. ${ }^{20}$

Efficacy: The percent of inhibition of the hydro alcoholic extract of W. somnifera leaves was $(54.49 \%), W$. somnifera roots $(50.73 \%)$ and $W$. somnifera root barks (50.80\%). W. somnifera root barks also significantly prevented the drop in PCV at dose levels of $600 \mathrm{mg} / \mathrm{kg}$ in comparison with the negative control group of mice $(p=0.004)$ and $W$. somnifera root and leaf extracts possess antidiabetic and antihyperlipidemic activities in alloxan-induced diabetic rats by another research. ${ }^{20,66}$

Other medicinal plants like, Osyris quadripartita, Vernonia amygdalina, Ajuga integrifolia, Melia azedarach, Peponium vogelii and Premna schimperi had also in vivo antimalarial activity and lack of toxicity. ${ }^{11,13,67-70}$ The methanol extract of A. integrifolia contained alkaloids, terpenoids, flavonoids, steroids, saponins, tannins, anthraquinone, phenols, fats and oils. Aqueous leaf extract of Vernonia amygdalina showed the presence of alkaloids, tannins, saponins, glycosides, and cardiac glycosides, with arthraquines and steroids in trace amount which was comparable with other study plus clinical trial of $V$. amygdalina in Uganda showed. $V$. amygdalina appears to be a moderately clinically effective and nontoxic treatment for malaria in adult semi-immune patients..$^{67,70-72}$

In the overall our ethnobotanical review data in (Table $1 \&$ Figure 1) reveals that, most Ethiopian community utilized several medicinal plants for the treatments of malaria especially in rural communities of the country. Some of the medicinal plant species studied by 
ethnobotanical survey and experimental study, in this study were also medicinally used for malaria treatment in other African countries. ${ }^{87-91}$ Allium sativum, Croton macrostachyus and Carica papaya were the more frequently cited species of medicinal plants by ethnobotanical study in Ethiopia for malaria treatment which was comparable to another study and Withania somnifera and Croton macrostachyus were commonly used by most of the traditional practitioners in other part of Ethiopia. ${ }^{92-94}$

Table I Ethno botanical studies of medicinal plants those used for the treatment of malaria

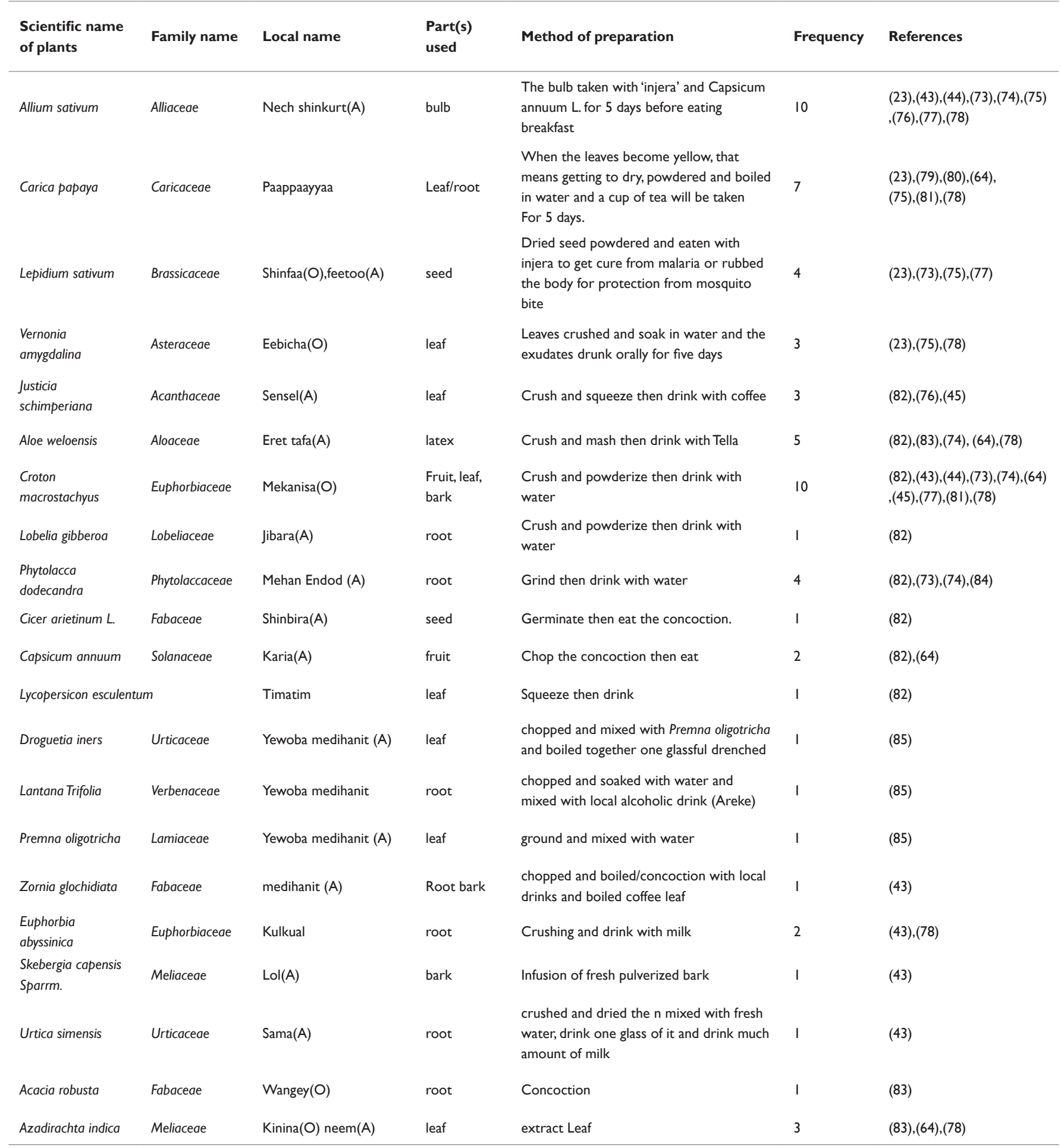


Table continued

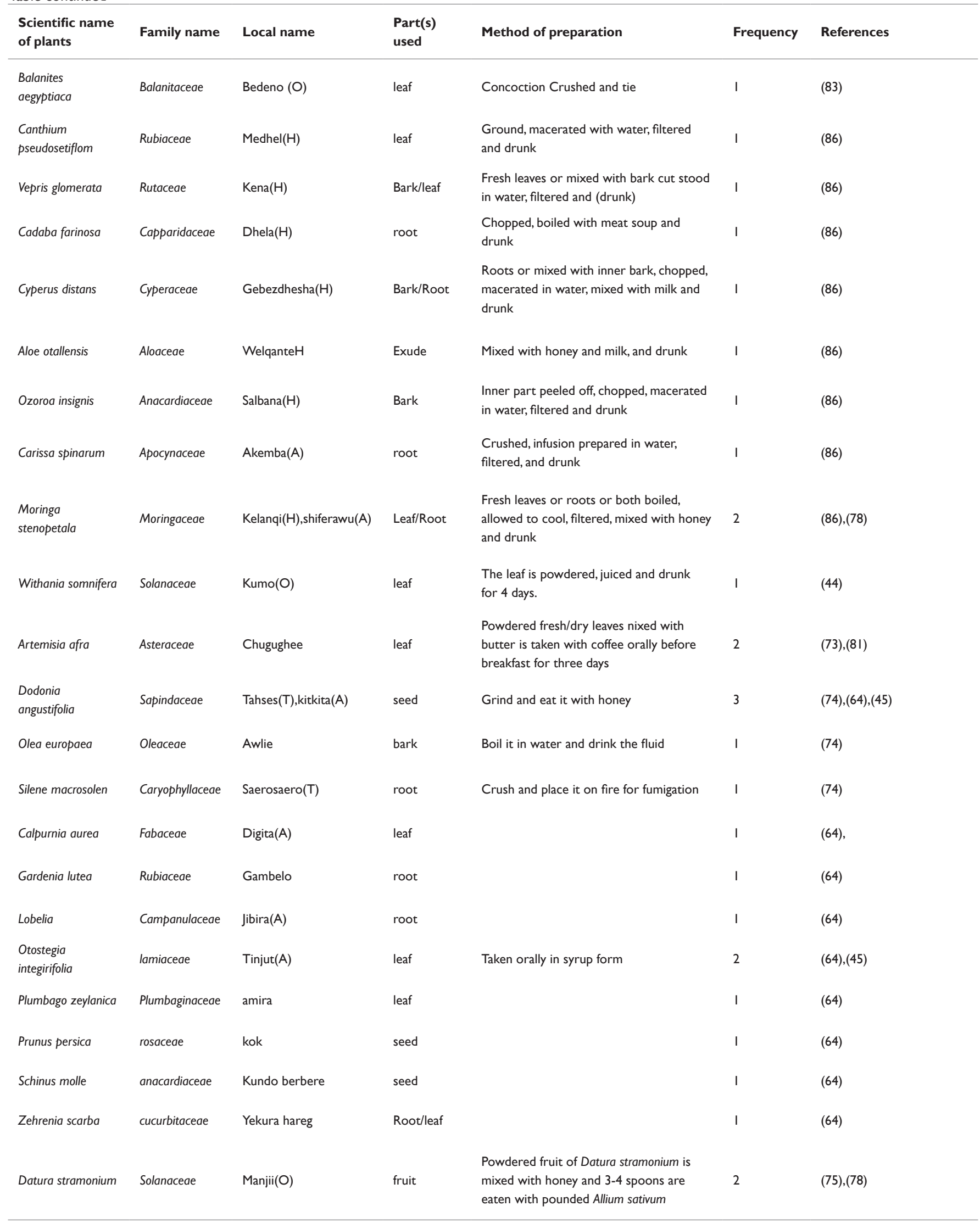




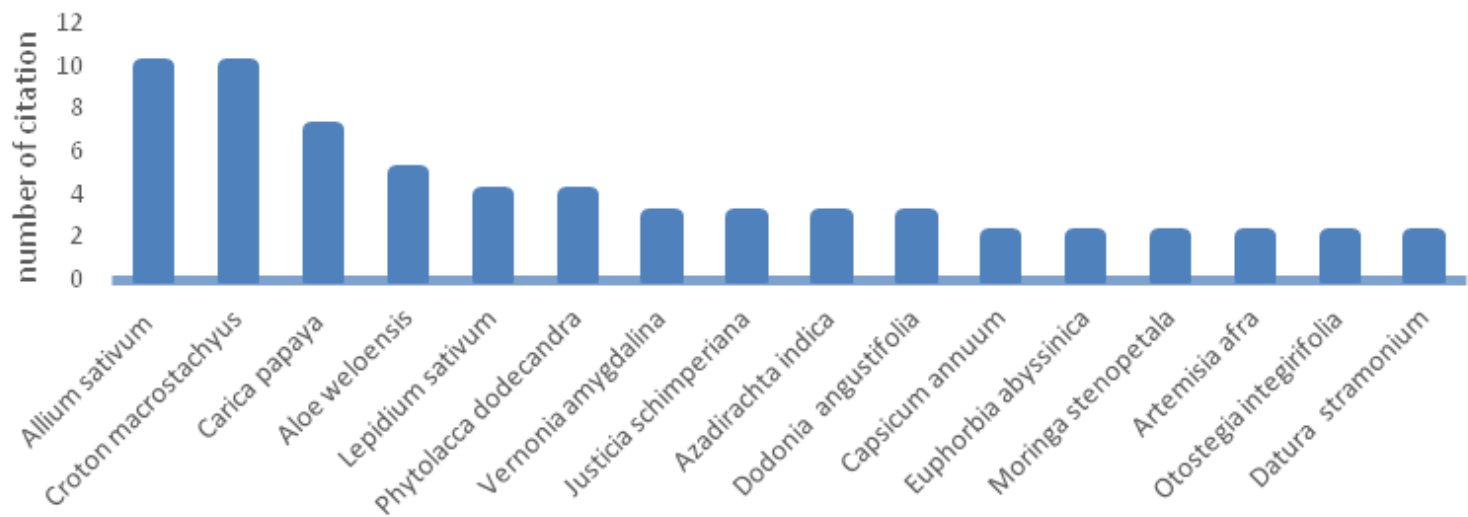

Scientific name of medicinal plants

Figure I More frequently cited medicinal plants for the treatment of malaria in Ethiopia.

\section{Conclusion and recommendation}

This review showed that aqueous leaf extract of Strychnos mitis possesses potent activity against $P$. berghei malaria parasite in vivo with a maximum percent chemo suppression of $95.5 \%$ at a dose of $600 \mathrm{mg} / \mathrm{kg} /$ day, however, further phytochemical analysis is necessary to isolate the compound which is active against $P$. berghei malaria parasite. The root of Croton macrostachys and ethyl acetate fractions of leaf extract of Dodonaea angustifolia also exhibited a significant parasite suppression. The hydroalcoholic root bark extract of Bersama abyssnica fresen showed sign of acute toxicity and chronic treatment of mice with aqueous root extract of Clerodendrum myricoides damage liver and kidney. The study highlighted phytochemistry, safety and efficacy of experimentally studied medicinal plants for malaria treatment in Ethiopia, except few studies further chemical isolation are necessary. Dosage form development, clinical trial and toxicological study is also recommended.

\section{Acknowledgments}

None.

\section{Conflicts of interest}

The authors have declared that there is no conflict of interest with regarding to the authorship and publication of this review article.

\section{References}

1. World malaria report 2017. WHO; 2017. $196 \mathrm{p}$.

2. World malaria report 2016. WHO; 2016. 186 p.

3. Deribew A, Dejene T, Kebede B, et al. Incidence, prevalence and mortality rates of malaria in Ethiopia from 1990 to 2015 : analysis of the global burden of diseases 2015. Malar J. 2017;16(1):271.

4. Ayele DG, Zewotir TT, Mwambi HG. Prevalence and risk factors of malaria in Ethiopia. Malar J. 2013;11:195.

5. Yewhalaw D, Kassahun W, Woldemichael K, et al. The influence of the
Gilgel-Gibe hydroelectric dam in Ethiopia on caregivers ' knowledge , perceptions and health-seeking behaviour towards childhood malaria. Malar J. 2010;9:47.

6. Birhanu Z, Abebe L, Sudhakar M, et al. Malaria Related Perceptions, Care Seeking after Onset of Fever and Anti-Malarial Drug Use in Malaria Endemic Settings of Southwest Ethiopia. PLoS One. 2016;11(8):e0160234.

7. Heuchert A, Abduselam N, Zeynudin A, et al. Molecular markers of anti-malarial drug resistance in southwest Ethiopia over time : regional surveillance from 2006 to 2013. Malar J. 2015;14:208.

8. Deressa W, Ali A. Malaria-related perceptions and practices of women with children under the age of five years in rural Ethiopia. BMC Public Health. 2009;9:259.

9. Abdissa D, Geleta G, Bacha K, et al. Phytochemical investigation of Aloe pulcherrima roots and evaluation for its antibacterial and antiplasmodial activities. PLoS One. 2017;12(3):e173882.

10. Minale G. In vitro antimicrobial and in vivo antimalarial evaluation of latex and compounds isolated from the leaves of aloe sinana Reynolds. 2nd International Conference and Exhibition on Pharmacognosy, Phytochemistry \& Natural Products: China; 2014.

11. Melariri P, Campbell W, Etusim P, et al. In vitro antiplasmodial activities of extracts from five plants used singly and in combination against Plasmodium falciparum parasites. Journal of Medicinal Plants Research. 2012;6(47):5770-5779.

12. Chinsembu KC. Plants as antimalarial agents in Sub-Saharan Africa. Acta Trop. 2015;152:32-48.

13. Girma S, Giday M, Erko B, et al. Effect of crude leaf extract of Osyris quadripartita on Plasmodium berghei in Swiss albino mice. $B M C$ Complement Altern Med. 2015;184(15):1-9.

14. Teka T, Bisrat D, Yeshak MY, et al. Antimalarial Activity of the Chemical Constituents of the Leaf Latex of Aloe pulcherrima Gilbert and Sebsebe. Molecules. 2016;21(11):E1415.

15. Paulos B, Bisrat D, Gedif T, et al. Antimalarial and Antioxidant Activities of the Leaf Exudate and a Naphthalene Derivative from Aloe otallensis Baker. Ethiopian Pharmaceutical Journal. 2011;29(2):100-107. 
16. Gemechu W, Bisrat D, Asres K. Antimalarial Anthrone and Chromone from the Leaf Latex of Aloe debrana Chrstian. Ethiopian Pharmaceutical Journal. 2014;30(1):1-9.

17. Sibhat G, Periasamy G. Analgesic activity of leaf latex of aloe percrassa todaro and aloe camperi schweinfurth in mice. World Journal of Pharmaceutical Research. 2015;4(6):355-361.

18. Deressa T, Mekonnen $\mathrm{Y}$, Animut A. In Vivo anti- malarial activities of Clerodendrum myricoides, Dodonea angustifolia and Aloe debrana against Plasmodium berghei. Ethiop J Health Dev. 2010; 24(1):25-29.

19. Ombito JO, Salano EN, Yegon PK, et al. A review of the chemistry of some species of genus Aloe (Xanthorrhoeaceae family). Journal of Scientific and Innovative Research. 2015;4(1):49-53.

20. Dikasso D, Makonnen E, Debella A, et al. In vivo anti-malarial activity of hydroalcoholic extracts from A sparagus africanus Lam . in mice infected with Plasmodium berghei. Ethiop J Health Dev. 2006;20(2):112-118.

21. Asrade S, Mengesha $\mathrm{Y}$, Moges $\mathrm{G}$, et al. In vivo antiplasmodial activity evaluation of the leaves of Balanites rotundifolia (Van Tiegh) Blatter (Balanitaceae) against Plasmodium berghei. J Exp Pharmacol. 2017;9:59-66.

22. Mengiste B. Antiplasmodial activity of extracts from dodonaea angustifolia 1.f. and bersama abyssinica fresen against plasmodium berghei in mice model; 2008.

23. Megersa M, Asfaw Z, Kelbessa E, et al. An ethnobotanical study of medicinal plants in Wayu Tuka District, East Welega Zone of Oromia. $J$ Ethnobiol Ethnomed. 2013;9(1):68.

24. Eyasu M, Shibeshi W, Giday M. In vivo antimalarial activity of hydromethanolic leaf extract of Calpurnia aurea (Fabaceae) in Mice infected with chloroquine sensitive Plasmodium berghei. The International Journal of Pharmacy and Pharmacology. 2013;2(9):131142.

25. Kebede H, Afework M, Makonnen E, et al. The Effect of Clerodendrum Myricoides Aqueous Extract on Blood, Liver and Kidney Tissues of Mice. MEJS. 2011;3(2):48-63.

26. Tadesse Y. Bioactivity Guided Study on the Antimalarial Activities of Clerodendrum myricoides and Dodonaea angustifolia; 2011.

27. Abebayehu A, Mammo F, Kibret B. Isolation and characterization of terpene from leaves of Croton macrostachyus (Bissana). Journal of Medicinal Plants Research. 2016;10(19):256-260.

28. Mekonnen LB. In vivo antimalarial activity of the crude root and fruit extracts of Croton macrostachyus (Euphorbiaceae) against Plasmodium berghei in mice. J Tradit Chinese Med Sci. 2015;5(3):168-173.

29. Bantie L, Assefa S, Teklehaimanot T, et al. In vivo antimalarial activity of the crude leaf extract and solvent fractions of Croton macrostachyus Hocsht. (Euphorbiaceae) against Plasmodium berghei in mice. BMC Complement Altern Med. 2014;14:79.

30. Mohammed T, Erko B, Giday M. Evaluation of antimalarial activity of leaves of Acokanthera schimperi and Croton macrostachyus against Plasmodium berghei in Swiss albino mice. BMC Complement Altern Med. 2014;14:314.

31. Obey JK, Ngeiywa MM, Kiprono P, et al. Antimalarial Activity of Croton macrostachyus Stem Bark Extracts against Plasmodium berghei In Vivo. Journal of Pathogens. 2018;2018:2393854.

32. Maroyi A. Ethnopharmacological Uses, Phytochemistry, and Pharmacological Properties of Croton macrostachyus Hochst. Ex Delile: A Comprehensive Review. Evidence-Based Complementary and Alternative Medicine. 2017;2017:1694671.

33. Karunamoorthi K, Ilango K. Larvicidal activity of Cymbopogon citratus (DC) Stapf . and Croton macrostachyus Del . against Anopheles arabiensis Patton, a potent malaria vector. Eur Rev Med Pharmacol Sci. 2010;14(1):57-62.

34. Dagne E, Melaku Y, Worku T, et al. Antiplasmodial Compounds from Leaves of Dodonaea angustifolia. Curr Bioact Compd. 2017;13(3):268273

35. Lawal D, Yunusa I. Dodonea Viscosa Linn: Its Medicinal, Pharmacological and Phytochemical Properties. International Journal of Innovation and Applied Studies. 2013;2(4):476-482.

36. Amelo W, Nagpal P, Makonnen E. Antiplasmodial activity of solvent fractions of methanolic root extract of Dodonaea angustifolia in Plasmodium berghei infected mice. BMC Complement Altern Med. 2014; $14: 462$.

37. Hymete A, Rohloff J, Iversen T, et al. Volatile constituents of the roots of Echinops kebericho Mesfin. Flavour and Fragrance Journal. 2007;22(1):35-38.

38. Hymete A, Hailu A, Rohloff J, et al. In vitro Evaluation of Antileishmanial Activity and Toxicity of Essential Oils of Artemisia absinthium and Echinops kebericho. Chem Biodivers. 2011;8(4):614-623.

39. Njoroge AH, Rohloff J, Njoroge TI. Chemical constituents of volatile fractions from Echinops ellenbeckii O. Hoffm. Journal of Essential Oil Bearing Plants. 2004;7(1):9-15.

40. Radulovic NS. Essential Oils from the Roots of Echinops bannaticus Rochel ex Schrad . and Echinops sphaerocephalus L. (Asteraceae): Chemotaxonomic and Biosynthetic Aspects. Chem Biodivers. 2013;10(4):658-676.

41. Toma A, Deyno S, Fikru A, et al. In vivo antiplasmodial and toxicological effect of crude ethanol extract of Echinops kebericho traditionally used in treatment of malaria in Ethiopia. Malar J. 2015;14:196.

42. Hailemeskel B, Fullas F, Habte A, et al. A review of natural remedies commonly used by Ethiopian immigrants in the USA. Curr Res Integr Med. 2017;2(3):31-36.

43. Wubetu M, Abula T, Dejenu G. Ethnopharmacologic survey of medicinal plants used to treat human diseases by traditional medical practitioners in Dega Damot district, Amhara, Northwestern. BMC Res Notes. 2017;10(1):157.

44. Abera B. Medicinal plants used in traditional medicine by Oromo people, Ghimbi District, Southwest Ethiopia. J Ethnobiol Ethnomed. 2014;10:40.

45. Gebeyehu G, Asfaw Z, Enyew A, et al. Ethnobotanical study of traditional medicinal plants and their conservation status in mecha wereda. International Journal of Pharmaceuticals and Health care Research. 2014;2(3):137-153.

46. Parixit Bhandurge, Rajarajeshwari N, Ganapaty S, et al. The Gnidia genus: A review. Asian Journal of Biomedical and Pharmaceutical Sciences. 2013;3(19):1-31.

47. Ghosh S, Derle A, Ahire M, et al. Phytochemical Analysis and Free Radical Scavenging Activity of Medicinal Plants Gnidia glauca and Dioscorea bulbifera. PLoS One. 2013;8(12):e82529.

48. Nigatu TA, Afework M, Urga K, et al. Toxicological investigation of acute and chronic treatment with Gnidia stenophylla Gilg root extract on some blood parameters and histopathology of spleen, liver and kidney in mice. BMC Res Notes. 2017;10(1):625.

49. Tilahun A, Nigatu TA, Afework M, et al. Effect of Oral Administration of Gnidia Stenophylla Gilg Aqueous Root Extract on Food Intake and Histology of Gastrointestinal Tract in Mice. Ethiop J Health Sci. 2017;27(1):35-46. 
50. Sahile S. In vitro anti-malarial activity of hydroalcoholic crude extract and its fractions of root of Gnidia stenophylla Gilg. on Plasmodium falciparum and in vivo parasitemia suppression studies on mice using the fractions on Plasmodium berghie. Addis Ababa university school of graduate studies; 2011.

51. Sharma AK, Gangwar M, Kumar D, et al. Phytochemica characterization, antimicrobial activity and reducing potential of seed oil , latex, machine oil and presscake of Jatropha curcas. Avicenna $J$ Phytomed. 2016;6(4):366-375.

52. Félix-silva J, Giordani RB, Silva AA, et al. Jatropha gossypiifolia L. (Euphorbiaceae): A Review of Traditional Uses, Phytochemistry, Pharmacology, and Toxicology of this Medicinal Plant. Evidence-Based Complementary and Alternative Medicine. 2014;2014:369204.

53. Tomass Z, Hadis M, Taye A, et al. Larvicidal effects of Jatropha curcas L. against Anopheles arabiensis (Diptera : Culicidea). Momona Ethiopian Journal of Science. 2011;3(1):1-5.

54. Inbaneson SJ, Ravikumar S, Suganthi P. In vitro antiplasmodial effect of ethanolic extracts of coastal medicinal plants along Palk Strait against Plasmodium falciparum. Asian Pac J Trop Biomed. 2012;2(5):364-367.

55. Fentahun S, Makonnen E, Awas T, et al. In vivo antimalarial activity of crude extracts and solvent fractions of leaves of Strychnos mitis in Plasmodium berghei infected mice. BMC Complement Altern Med. 2017;17(1):13.

56. Mallikharjuna PB, Rajanna LN, Seetharam YN, et al. Phytochemica Studies of Strychnos potatorum L. f.-A Medicinal Plant. E-Journal of Chemistry. 2007;4(4):510-518.

57. Frederich M, Hayette M, Tits M, et al. In Vitro Activities of Strychnos Alkaloids and Extracts against Plasmodium falciparum. Antimicrob Agents Chemother. 1999;43(9):2328-2331.

58. Chekol YA, Desta ZY. Determination of antioxidant and antimicrobial activities of leaf extracts of Otostegia integrifolia. Chem Cent J. 2018;12(1):63.

59. Shewamene Z, Abdelwuhab M, Birhanu Z. Methanolic leaf exctract of Otostegia integrifolia Benth reduces blood glucose levels in diabetic , glucose loaded and normal rodents. BMC Complement Altern Med. $2015 ; 15: 19$

60. Sadeghi Z, Akaberi M, Valizadeh J. Otostegia persica (Lamiaceae): A review on its ethnopharmacology, phytochemistry, and pharmacology. Avicenna J Phytomed. 2014;4(2):79-88.

61. Endale A, Bisrat D, Animut A, et al. In vivo Antimalarial Activity of a Labdane Diterpenoid from the Leaves of Otostegia integrifolia Benth. Phytother Res. 2013;27(12):1805-1809.

62. Yeshanew S, Mekonnen Y. The Effect of Otostegia integrefolia Leaf Extracts on the Packed Cell Volume, Body Weight and Survival Time of Plasmodium berghei Infected Mice. Int J Trop Med. 2013;8(5):129-134.

63. Nateghpour M, Farivar L, Souri E, et al. The Effect of Otostegia persica in Combination with Chloroquine on Chloroquine-Sensitive and Chloroquine-Resistant Strains of Plasmodium berghei Using In-vivo Fixed Ratios Method. Iran J Pharm Res. 2012;11(2):583-588.

64. Giday M, Teklehaymanot T, Animut A, et al. Medicinal plants of the Shinasha, Agew-awi and Amhara peoples in northwest Ethiopia. $J$ Ethnopharmacol. 2007;110(3):516-525.

65. Mirjalili MH, Moyano E, Bonfill M, et al. Steroidal Lactones from Withania somnifera, an Ancient Plant for Novel Medicine. Molecules. 2009; 14(7):2373-2393.

66. Udayakumar R, Kasthurirengan S, Mariashibu TS. Hypoglycaemic and Hypolipidaemic Effects of Withania somnifera Root and Leaf Extracts on Alloxan-Induced Diabetic Rats. Int J Mol Sci. 2009;10(5):2367-2382.
67. Sha A. In vitro antimalarial activity of the extracts of vernonia amygdalina commonly used in traditional medicine in Nigeria. Science World Journal. 2011;6(2):5-9.

68. Abdullahi MI, Uba A, Yunusa A, et al. Evaluation of the Anti-malarial effect of the methanolic leaf extract of Vernonia glaberrima (Asteraceae). IOSR Journal of Pharmacy and Biological Sciences. 2015;10(5):6-9.

69. Masaba SC. The antimalarial activity of Vernonia amygda/in a Del (Compositae). Trans R Soc Trop Med Hyg. 2000;94(6):694-695.

70. Asnake S, Teklehaymanot T, Hymete A, et al. Evaluation of the antiplasmodial properties of selected plants in southern Ethiopia. BMC Complement Altern Med. 2015;15:448.

71. Odeh AP, Usman A. Antimalarial activity and phytochemical analysis of aqueous leaf extract of Vernonia amygdalina. Journal of Zoological and Bioscience Research. 2014;1(3):28-31

72. Willcox M, Challand S. A Clinical Trial of the Traditional Medicine Vernonia amygdalina in the Treatment. J Altern Complement Med. 2009;15(11):1231-1237.

73. Mesfin F, Demissew S, Teklehaymanot T. An ethnobotanical study of medicinal plants in Wonago Woreda, SNNPR, Ethiopia. J Ethnobiol Ethnomed. 2009;18.

74. Teklay A, Abera B, Giday M. An ethnobotanical study of medicinal plants used in Kilte Awulaelo District, Tigray Region of Ethiopia. $J$ Ethnobiol Ethnomed. 2013;9(1):65.

75. Medicinal MOF, By P, People I, Shoa W, Approach ANE. School of graduate studies; 2007

76. Zerabruk S, Yirga G. Traditional knowledge of medicinal plants in Gindeberet district, Western Ethiopia. South African J Bot. 2012;78:165169

77. Asnake S, Teklehaymanot T, Hymete A, et al. Survey of Medicinal Plants Used to Treat Malaria by Sidama People of Boricha District, Sidama Zone, South Region of Ethiopia. Evid Based Complement Alternat Med. 2016;2016:9690164.

78. Tefera BN, Kim Y. Ethnobotanical study of medicinal plants used as antimalarial and repellent by Sidama people of Hawassa Zuria district Southern Ethiopia. J Complement Med Res. 2019;10(1):13-26.

79. Teklehaymanot T, Giday M. Ethnobotanical study of medicinal plants used by people in Zegie Peninsula, Northwestern Ethiopia. J Ethnobiol Ethnomed. 2007;3:12.

80. Giday M, Asfaw Z, Woldu Z, et al. Medicinal plant knowledge of the Bench ethnic group of Ethiopia: an ethnobotanical investigation. $J$ Ethnobiol Ethnomed. 2009;5:34

81. Amsalu N, Bezie Y, Fentahun M, et al. Use and Conservation of Medicinal Plants by Indigenous People of Gozamin Wereda , East Gojjam Zone of Amhara Region, Ethiopia : An Ethnobotanical Approach. Evid Based Complement Alternat Med. 2018;2018:2973513.

82. Chekole G. Ethnobotanical study of medicinal plants used against human ailments in Gubalafto. J Ethnobiol Ethnomed. 2017;13(1):55.

83. Belayneh A, Asfaw Z, Demissew S, et al. Medicinal plants potential and use by pastoral and agro-pastoral communities in Erer Valley of Babile Wereda , Eastern Ethiopia. J Ethnobiol Ethnomed. 2012;81:42.

84. Avigdor E, Wohlmuth H, Asfaw Z, et al. The current status of knowledge of herbal medicine and medicinal plants in Fiche, Ethiopia. $J$ Ethnobiol Ethnomed. 2014;10:38.

85. Tolossa K, Debela E, Athanasiadou S, et al. Ethno-medicinal study of plants used for treatment of human and livestock ailments by traditional healers in South Omo, Southern. J Ethnobiol Ethnomed. 2013;91:32. 
86. Paulos B, Fenta TG, Bisrat D, et al. Health seeking behavior and use of medicinal plants among the Hamer ethnic group, South Omo zone, southwestern Ethiopia. J Ethnobiol Ethnomed. 2016;12(1):44.

87. Ngarivhume T, Van CIEA, Jong JTVM De, et al. Medicinal plants used by traditional healers for the treatment of malaria in the Chipinge district in Zimbabwe. J Ethnopharmacol. 2015;159:224-237.

88. Asase A, Oteng-yeboah AA, Odamtten GT, et al. Ethnobotanica study of some Ghanaian anti-malarial plants. J Ethnopharmacol. 2005;99(2):273-279.

89. Mukungu N, Abuga K, Okalebo F, et al. Medicinal plants used for management of malaria among the Luhya community of Kakamega East sub-County, Kenya. J Ethnopharmacol. 2016;194:98-107.

90. Moshi MJ, Otieno DF, Weisheit A. Ethnomedicine of the Kagera Region, north western Tanzania. Part 3: plants used in traditional medicine in Kikuku village, Muleba District. J Ethnobiol Ethnomed. 2012;8(1):14.
91. Ramalhete C, Lopes D, Mulhovo S, et al. Antimalarial activity of some plants traditionally used in Mozambique. Workshop Plantas Medicinais e Fitoterapêuticas nos Trópicos; 2008. 9 p

92. Alebie G, Urga B, Worku A. Systematic review on traditional medicinal plants used for the treatment of malaria in Ethiopia: trends and perspectives. Malar J. 2017;16(1):307.

93. Lulekal E, Kelbessa E, Bekele T, et al. An ethnobotanical study of medicinal plants in Mana Angetu District, southeastern Ethiopia. $J$ Ethnobiol Ethnomed. 2008;4:10.

94. Bekalo TH, Woodmatas SD, Woldemariam ZA. An ethnobotanical study of medicinal plants used by local people in the lowlands of Konta Special Woreda, southern nations, nationalities and peoples regional state, Ethiopia. J Ethnobiol Ethnomed. 2009;5:26. 